who would postpone this inevitable economic process, which is why it is a pity that he has not elected to be hung for a sheep and not just a lamb. It is also unfortunate that he has not included in his new statement some echo of the declaration in the House of Commons last July that in the seventies the competing fuel industries will have to find their own level by price competition in the open market.

But what should be the Government's policy on coal? This is where the ministry may have been too much distracted by the enthusiasm with which it has recently been converted to the doctrine of discounted cash flows as a means of comparing the value of alternative investments. The plain truth is that the market for coal in the 1980s will consist simply of two kinds of customers-the steel works which use coal as a chemical reducing agent and those electricity power stations which, for geographical reasons or simply because they happen to exist, can economically make use of the fuel. There may also, of course, be private persons who continue to burn coal in their houses more out of nostalgia for what will then be the past than as a means of keeping warm. In other words, with luck, Lord Robens' successor in the mid seventies may have to conjure with a natural demand for coal of between 50 and 75 million tons a year. In these circumstances the courageous policy is not so much to fix an acceptable rate of decline for the years immediately ahead as to plan deliberately for what should be a continuing reduction of the scale of the coal industry in the next two decades.

The question is important not merely because coal employs 370,000 miners but also because problems of industrial obsolescence will be increasingly frequent in the years ahead. It is also plain that the concentra-

\section{The Future for Coal}

"ThIs is a very complex subject," said Mr Richard Marsh, Minister of Power, warming to the task of presenting his Fuel Policy White Paper on November 14. Complex it may be, but this has not deterred the mining industry, and its supporters, from protesting very loudly about the rapid run-down of the mining industry. Mr Marsh was wise enough not to ignore their fears, but he did say that the manpower figures quoted for 1980-and inspired by the Coal Boardhad "no validity whatsoever". "It's impossible to produce serious figures this far ahead." On the contrary, the coal mining industry would remain one of the biggest industries in Britain, producing 120 million tons in 1975, just over a third of Britain's total energy requirement. The claim that the ministry was "slashing the coal industry" could not be sustained in the light of the White Paper. Mr Marsh admitted that the figures would probably bo wrong-"Every estimate of coal burning since the War has been too high"-but they were indications of the way things were going, and they could readily be adjusted if necessary.

What the White Paper does is to re-work the estimates made in a previous white paper in 1965. Since then, the emergence of nuclear power as a cheaper source of electricity than coal, and the discovery of tion of the coal industry in particular parts of Britain means that social problems are not thinly spread about the country but, rather, concentrated painfully. How then to deal with them? The Government has accompanied its new policy for fuel with a number of schemes for softening the blows that will fall in mining communities in the years ahead. There are to be pensions for miners over 55 thrown out of work by the closing down of collieries, and other financial devices operated through the National Coal Board. These should go some way to sweetening the bitter pill the miners will have to swallow, but they will of necessity only comfort the older part of the mining population. Indir ectly, however, the industry as a whole will benefit from the way in which the Government is arranging that the industry's need of capital investment in the years ahead shall be provided almost entirely from public funds and not out of the industry's own revenue.

By themselves, however, these measures will only scratch the surface of the social problem of a rapidly declining coal industry. The other half of the Government's policy is to offer further incentives for industries to establish themselves in mining areas. But the Government should pay still more attention to the need for a vigorous retraining programme for people thrown out of work by technical change in industry. Given the scale on which the Ministry of Power now hopes to win economic benefit by a shift of emphasis in the fuel industries, it would not be unreasonable if several tens of millions of pounds a year were spent on retraining programmes for miners. For retraining is in its way an investment, just as is the building of new pipelines or new power stations. By comparison, increased doles are merely a palliative, necessary though they may occasionally be.

natural gas in the North Sea, have overturned the assumptions which it was then possible to make. Despite this, and an appendix to the White Paper which argues the case for nuclear power in terms which might almost convince Lord Robens, no increase is being made in the second nuclear power programmeit will still be $8,000 \mathrm{MW}$ by 1975 . By then, natural gas will represent 50 million tons of coal equivalent, and oil will be the major source of power, providing 145 million tons of coal equivalent.

Until 1970, Mr Marsh said, the gas and electricity industries had been persuaded to burn an extra 6 million tons of coal a year. The extra cost of this, £45 million, would be met by the Government and not the consumer. Foreign coal will continue to be banned, and oil will continue to be taxed. To alleviate hardship in the industry, the Government is proposing new legislation - the Coal Industry Bill-which will increass the amount the Government contributes towards the costs of redundancy or redeployment. Men between the ages of 55 and 65 who lose their jobs will get a high proportion of their previous wage for three years, or until they are 65. After this they will get their mineworker's pension immediately. There are also to be steps to encourage new industry to areas where pits 
will be closed. The Board of Trade is establishing "super-development areas" within existing development areas. The attractions for industry will be even greater-a Board of Trade factory rent-free for five years, for example. Building grants and loans at moderate rates of interest will also be available. This will be costing a total of $£ 100$ million in the period up to 1971 .

What emerges from all this ? First, the coal industry will continue to contract, although the special arrangements will slow the process down in the difficult years up till 1970. Natural gas will go ahead fast, and oil will continue to expand, whatever obstacles are put in its way. Nuclear power will do no more than hold its own, at least until 1970. After that, Mr Marsh may be able to get back to the cheap fuel policy he set his heart on when he first became minister.

\section{Nuclear Confusion}

THERE is increasing impatience in industry, and in the Atomic Energy Authority, over the Government's reluctance to announce new plans for the organization of nuclear power in Britain. For the past six months it has been clear that some sort of reorganization is inevitable, but it is still doubtful what form it will take. Part of the responsibility for the delay must be laid at the door of the Select Committee on Science and Technology, which will publish on November 22 its report on the nuclear power industry. The Government is using the report as an excuse, if not for inaction, at least for declining to comment.

Reformers divide into two schools. One, led by the Atomic Energy Authority, favours the setting up of a central design authority, which would do research and design new stations. Individual parts of power stations would be put out to tend $r$, but the formal structure of the consortia would be broken down. Overseas the AEA would tender for contracts, and would be responsible for the export work now done by the British Nuclear Export Executive. Only one consortium, Atomic Power Constructions Ltd, favours this solution.

The other two consortia, and the Central Electricity Generating Board, favour an arrangement which retains at least an element of commercial competition. (The AEA sometimes argues that competition from the USA is going to be more than enough to keep nuclear power in Britain on its toes.) It is generally accepted that the number of consortia would be reduced to two, possibly by a merger between Atomic Power Constructions and Nuclear Design and Construction. The two ministries involved, the Ministry of Technology and the Ministry of Power, agree that discussions have been going on between them, but decline to say what, if anvthing, has been decided. The Minister of Power, Mr Richard Marsh, did agree with the select committee that the question of the single design authority was crucial. "It is one of the biggest arguments involved in this particular issue."

But this was as long ago as June. Since then, little has been done to clarify the position. It is unlikely, though, that this silence can be taken as evidence of a division of opinion between the two ministries. Reports that the Government is preparing legislation to compel the formation of one central design authority are also heavily discounted in Whitehall. No mention was made of such legislation in the Queen's Speech, and it would be very hard to find room for it in the parliamentary calendar. But if the idea of a single design authority has found favour, it is hard to see how it could be imposed except by legislation. The only alternative would be to force the consortia into line by an $\mathrm{f}$ dict from the Central Electricity Generating Board, which buys the stations. If the buying policies of the CEGB were manipulated, then there is no doubt that a single design authority could emerge. The CEGB need only say that in future it would buy stations only from the AEA, and the consortia would soon be forced to knuckle under. Unfortunately for supporters of the idea, the CEGB has not always seen eye to eye with the AEA, and does not approve of the idea of a monopoly design authority. Thus if the Ministry of Technology is really wedded to the idea of a single design authority-and there is some evidence that it is not-it may have to force the idea through the CEGB.

\section{Barriers to Collaboration}

ExPORT efforts by British firms are often hindered by tariff barriers. One possible answer is to collaborate with foreign firms and either set up partly owned subsidiaries in the countries concerned or let the foreign companies make the product under licence. Although this sounds simple, Mr C. de Hoghton, author of a report called Cross-Channel Collaboration published by Political and Economic Planning (PEP), points out that there are many pitfalls because of different licensing laws, language barriers, the difficulty of finding the right company and the lack of comprehensive advice. Provided the company's outlook is realistic, however, it should not find collaboration with a European firm intrinsically more difficult than collaboration with a firm at home.

$\mathrm{Mr}$ de Hoghton points out that there is a profusion of sources of advice and assistance, but these sources are not used because firms are unaware of their existence. In some cases they offer only partial advice and help and they are distrusted, or the companies fail to recognize the need, in certain circumstances, for outside assistance. He recommends that an Institute of Industrial Licensing should be set up as a competently staffed clearing-house to assist firms in the profitable exploitation of their know-how abroad. A pilot scheme, limited to Western Europe, might be run by the British National Export Council.

Among the other recommendations Mr de Hoghton makes are that it should be standard drill for companies to comb through their product lines and their research and development to id ntify items which could be licensed abroad or exploited by other appropriate means in foreign countries. Both Government and private bodies should give greater publicity to the advantages of collaboration, and especially of collaboration with European firms. Consultants should concern themselves more actively with the whole range of issues raised by collaboration. Trade associations should consider what additional help they could give members who want to collaborate and should always become members of international European associations where they exist, seeking to be admitted as observers to those European associations limited to the EEC. 